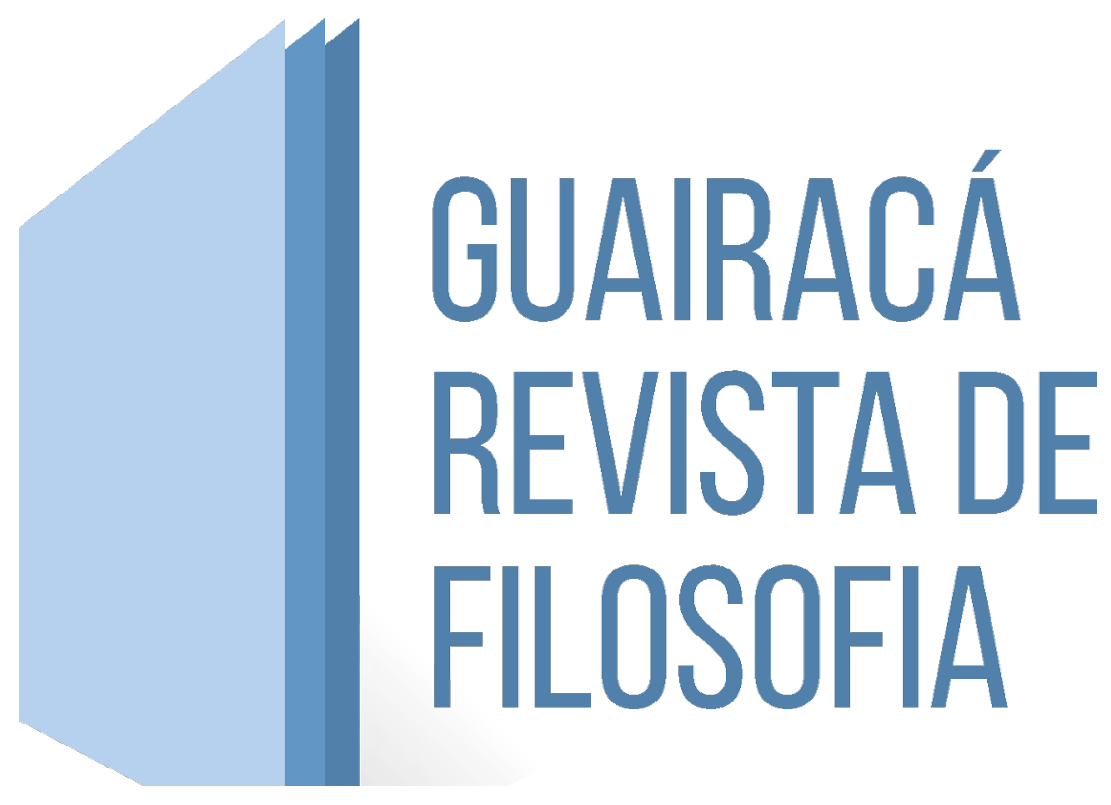

\title{
APONTAMENTOS SOBRE O CETICISMO PIRRÔNICO: ENTRE A CRIITICA À RACIONALIDADEE A DEFESA DA VIDA COMUM
}

Resumo: O presente artigo consiste em uma investigação sobre o ceticismo pirrônico em vista da crítica dos pirrônicos às filosofias que defendem ser a investigação filosófica superior à vida comum. Em um primeiro momento apresentaremos um esboço da postura pirrônica, visando mostrar que os céticos utilizam o ceticismo como cura que visa retirar dos homens a presunção em querer julgar as coisas em si mesmas. Os céticos pirrônicos desenvolvem uma crítica aos dogmáticos e aos acadêmicos porque ambos, ao filosofarem, se comprometem em proporcionar duas coisas que os mesmos não alcançam: verdades absolutas e a felicidade. Neste sentido, para os seguidores da sképsis, a filosofia deve curar os homens pelo discurso ao invés de promover o tormento e a insatisfação pelas contínuas disputas filosóficas em busca por pretensas verdades absolutas. Discutiremos sobre alguns importantes conceitos que compõem o percurso realizado pela zétesis (investigação) pirrônica, como os conceitos de Equipolência, Anomalia, Epokhé, Acatalepsia, Ataraxia e Afasia. Por fim, problematizaremos a crítica pirrônica à racionalidade a partir da defesa das aparências e da vida comum.

Palavras Chave: Ceticismo, Pirro, Ataraxia.

1. Professor Efetivo do Curso de Filosofia da Universidade Estadual de Roraima. Doutor em Filosofia pela Unicamp 


\title{
NOTES ABOUT THE PYRRHONISM SKEPTICISM: BETWEEN THE CRITIC OF RATIONALITY AND THE DEFENSE OF THE COMMON LIFE
}

\begin{abstract}
This article is an investigation about the pyrrhonian skepticism, in view of pyrrhonians criticism about the philosophies that advocate that philosophical inquiry be more important than ordinary life. At first, we present a summary of pyrrhonic posture, intending to show that skeptics use skepticism as a healing that aims to eliminate the presumption of men who want to judge things in themselves. Skeptics pyrrhonians develop a critique for then dogmatics and academics because both, when philosophize, have pledged to provide two things that they don't reach: absolute truths and happiness. In this effect, to the followers of the skepsis the philosophy should heal men by speech instead of promoting the misery and dissatisfaction by continuing philosophical disputes in alleged pursuit of absolute truths. We discuss about some important concepts that comprise the route taken by Zetes (research) pyrrhonic, as the concepts of balance, Anomaly, epoché, Acatalepsy, Ataraxia and aphasia .Finally we question the rationality yrrhonic criticism from the defense of the appearances and of the ordinary life.
\end{abstract}

Key Words: Skepticism, Pirro, Ataraxia.

\section{SOBREA POSTURA PIRRÔNICA}

Pirro de Élis (360-270 ac.) é considerado o iniciador do movimento cético grego, por isso o ceticismo seguido por ele foi intitulado ceticismo pirrônico. Pirro não defendia um ceticismo teórico, pelo contrário, era conhecido como um homem que vivia o estado da dúvida, que colocava tudo em dúvida, ao não comprometer nenhum de seus juízos sobre como as coisas são, mas apenas assentia sobre como as coisas lhe pareciam ser. Filósofo enigmático, a postura de Pirro chamou a atenção dos filósofos de sua época, principalmente ao procurar evitar a infelicidade que é causada pelas investigações teóricas, que sempre são frustradas por não alcançarem o que pretendem. Uma das principais teses de Pirro era a consideração de que não há nada existente em si mesmo, e que o costume e a convenção são tudo o que convém a ação humana, por isso a governam. Sobre o tema, Diógenes Laêrtios explica que:

Pírron afirmava que nada é honroso ou vergonhoso, nada éjusto ou injusto, e aplicava igualmente a todas as coisas o princípio de que nada existe realmente, sustentando que todos os atos humanos são determinados pelo hábito e pelas convenções, pois cada coisa não é mais isto que aquilo (DIÔGENES, 1997, p. 267-268). 
Notemos que o cético pirrônico acredita ser um filantropo, ao querer curar os homens por meio do discurso, visa retirar tanto quanto conseguir, a presunção humana em querer julgar as coisas em si mesmas. É assim que os pirrônicos consideram nada determinar sobre as coisas em si mesmas. $\mathrm{O}$ não assentimento não exime o cético da investigação. $\mathrm{O}$ cético, neste caso, é um grande inquiridor, mas ele se reserva o direito de não assentir, pois a todo argumento encontra um que lhe contrapõe, com razões que anulam a primeira asserção. Ora, nessa teoria do conhecimento, caso usemos tal terminologia anacrônica, tudo o que há de conhecimento seriam as aparências (aisthesis), ou juízos perceptuais, e o não conhecimento das coisas em si.

Segundo Plínio J. Smith, o ceticismo considera que para atribuir a alguém um verdadeiro conhecimento, cumpre realizar-se plenamente "três condições: a) Ela precisa crer no que diz (ou pensa); b) sua crença tem que ser verdadeira; c) ela precisa dar uma boa razão ou justificar adequadamente a sua crença. Por isso, o conhecimento é definido como uma crença verdadeira justificada" (SMITH, 2004, p. 10).

A questão da crença é fundamental para a tradição cética. Crer, validadeverdade de tal crença, razões que justifiquem tal pretensão de verdade. No seio dessa estrutura, há uma chave investigativa precisa que promove um filtro radical. A definição extraída dessa tríplice condição é apontada pelos céticos como um mecanismo que por si mesmo impossibilita a descoberta de qualquer verdade absoluta. Em todo caso, quanto à proposição (a), ela é cumprida como que naturalmente, pois o ser humano possui crenças e lhe é fácil assentir que elas sejam de um modo em detrimento de outro. Realizar atos de crença, ou atos de escolha, neste sentido, são atos acessíveis a todos. A arbitrariedade de tal escolha faz que o agravante de uma possível negação da possibilidade de assentir seja absurdo ou não humano. Podemos dizer, pois, que assentimos porque o queremos e isso basta. Porém, a situação não é a mesma com as outras duas, visto que o modelo cético aponta problemas inerentes às condições (b) e (c). Para os pirrônicos, ocorre que toda justificação de nossas crenças pretensamente verdadeiras é sempre dubitável e problemática. O âmbito dúbio de (b) e (c) remete ao problema da justificação racional, enquanto no caso de (a), estamos no reino da escolha ou da opinião.

Os céticos, considerando o esquema genérico que estamos trabalhando segundo a proposta didática de Plínio J. Smith, discute de forma que a proposição (b), ao ser atacada, ela depende de (c), enquanto que (c), para ser sustentável, supõe a validade de (b), o que parece levar à uma circularidade. Neste caso, ao investigar e indagar sobre os mais diversos assuntos, o resultado é que se mostra reiteradamente certa estrutura argumentativa que leva toda e qualquer pretensa verdade a ser desqualificada. Ora, (a) "nós precisamos inferir a partir de certas evidências; mas 
(b) nenhuma inferência a partir das evidências é segura ou confiável; logo, (c) não há como justificar nosso conhecimento com base nas evidências de que dispomos". (SMITH, 2004, p. 19)

A norma do conhecer assertivo é minada e o cético refugia-se no âmbito das aparências. Ao firmar-se tão somente nas aparências, não há uma pretensa posse de conhecimentos objetivos, mas de opiniões que se sucedem, se modificam, se opõem umas às outras conforme a ocasião. Sem condições de determinar o que são os objetos reais externos, não podemos justificar a precisão ou imprecisão das crenças que temos a respeito de realidades externas. A explicação a partir do neopirronismo de Porchat, quanto a esse tema, é precisa, vejamos:

[...] o critério da escola cética, é o "fenômeno" (tò phainómenon), isto é, aquilo que nos aparece; em verdade, assim denominamos o que é virtualmente a representação (phantasía) do que aparece (cf. H.P. I, 22), de fato uma afecção (páthos) nossa e uma afecção involuntária. E essa representação passiva (phantasía pathetiké) induz nosso assentimento involuntário a ela (PORCHAT, 2007, p. 75-76).

Por aparências, os pirrônicos estão se referindo tão somente aos objetos de percepção sensível. Contrariando a tradição platônica, a qual supunha a superioridade do "nous" (inteligência) sobre a "doxa" (aparências ou opiniões), o ceticismo, ao modo pirrônico, resgata o valor do aparecer em sua dinamicidade. Como estes objetos sensíveis não são os mesmos em cada situação e para cada homem, há um grande contraste entre aparências e objetos de pensamento (juízos). Por esta oposição ocorre uma equipolência entre o que se apresenta pelos objetos sensíveis e as razões justificadas pelos objetos de pensamento. A equipolência emerge dessa relação de igualdade, pois entre o mais provável e o menos não temos um critério de verdade infalível, e, portanto, confiável, de modo que alcançamos tão somente a crença infundada de que as coisas podem ocorrer de um modo mais que outro.

A coerência do pensamento cético sempre foi contestada ao longo da história da filosofia. Visto que se os céticos procuram refutar todas as asserções, os argumentos que eles utilizariam para isso seriam, de algum modo, um critério de verdade. Ocorre que os céticos pensam de outra forma. Eles se deram conta de que a refutação de toda e qualquer asserção iria ter por consequência a refutação de suas próprias asserções que refutam aquelas. Sobre essa característica de se auto-refutar, é interessante o conhecido exemplo de Apeles, tal qual aparece na obra de Sexto Empírico:

Ocorre ao cético o mesmo que, segundo se diz, sucedeu ao pintor Apeles; pois contam que ele pintando um cavalo, de tal modo fracassava em seu intento de representar a espuma do corcel, que desesperou de lograr-lo e lançou contra o quadro a esponja 
em que limpava as cores do pincel; mas então a esponja, ao dar contra a pintura, trouxe a imagem da espuma. (H.P. I, Cap. XII, p. 92, 1996)²

Quanto ao exemplo, o pintor Apeles não pretendia alcançar o que realmente desejava, pois já estava desacreditando seu próprio intento. Mas, em um ato do acaso, em expressando seu descontentamento, alcançou o objetivo anteriormente almejado. Ora, o acaso faz que ocorra uma solução surpreendente. Neste caso, o percurso inquiridor do cético pirrônico pode ser compreendido a partir dessa metáfora, pois da primeira situação segue-se outra:

[...] assim, também os céticos esperavam alcançar a imperturbabilidade resolvendo a contradição entre aparências e juízos; mas, não podendo consegui-lo; suspenderam o juízo; já que haviam suspendido o juízo lhes veio pouco a pouco, fortuitamente, a imperturbabilidade, tal como a sombra segue o corpo (H.P. I, Cap. XII, p. 92, 1996).

De um modo geral, a historiografia filosófica considera que, para o cético pirrônico, talvez, não existam o belo e o feio, o justo e o injusto, a verdade e a falsidade. A validade objetiva do saber está posta em suspeição, tal que, em si mesmas, as coisas não são mais isto que aquilo. O resultado não é outro que a impossibilidade de estabelecer diferenças categóricas entre as coisas. Por sua vez, o cético procura outro caminho que aquele proposto pelos dogmáticos. Segundo este viés, sobre as coisas em si mesmas, o cético torna-se indiferente. Contudo, essa indiferença não implica em omissão, pelo contrário, o cético age, vive, opina e goza a vida como todos, mas ele exerce esse modo de viver no plano da ação, da vida comum. Por um lado, a dúvida, tão cruel e perversa, para o cético, é um macio e agradável travesseiro! No plano filosófico, ele se mantém protegido pelas razões da dúvida. Acontece, pois, que sobre essa proteção da dúvida há um caminho que leva a alcançar a imperturbabilidade do espírito, que reenvia ao sentimento de gozar uma vida feliz.

\section{CONCEITOS FUNDAMENTAIS MANFESTOS NO PERCURSO CÉTICO}

Neste contexto amplo e didático traçado por essas nossas observações sobre a postura cética, segundo os fins propostos neste artigo, problematizaremos o percurso cético pirrônico a partir da relação entre os seguintes elementos que o compõe: Zétesis; Equipolência; Anomalia; Epokhé; Acatalepsia; Ataraxia.

2. Conforme a praxe, para as citações das Hipotiposis Pirronianas, de Sexto Empírico, usamos as sigla "H.P" entre parêntesis, sem que mencionemos o nome do autor, por economia. Na sequência temos o número romano que corresponde ao livro e na sequência o capítulo específico, seguido do ano da edição. 
Zétesis: Significa investigação. O cético é aquele que, como todo mundo, se coloca a investigar e a indagar. A humanidade do ser humano possui essa marca. A dúvida é característica da natureza humana e a investigação não é outra coisa que a expressão dessa humanidade. Investigar é inspecionar as próprias opiniões, adquirindo novas crenças ou substituindo as antigas por outras que se apresentarem melhores. No acontecer temporal de cada vida, decorre que as opiniões são emitidas e relançadas umas sobre as outras, segundo certas inquirições. E, se toda inquirição é sempre uma aquisição, de algum modo, ainda que no contexto cético, todo aquele que examina as próprias opiniões sempre aprende algo. Conhecer, pois, não é adquirir objetividade de conhecimentos válidos segundo a natureza das coisas, mas é aprender por si mesmo no contínuo fluir da absorção peculiar do que nos toca no aparecer. Ora, para o cético, esse é sim um aprendizado fundamental que é contínuo e jamais termina. Por falta de um critério que garanta um absoluto e indiscutível acesso à verdade absoluta, os céticos não creem em verdades que levariam ao término da investigação filosófica, de forma que se mantém na experiência irredutível da investigação.

Equipolência: Há um conflito equipolente ante as razões em disputa. Segundo este conflito, na relação de oposição entre razões, decorre que os dois discursos expõem argumentos de igual força. Essa equipolência entre os discursos é decorrente da igualdade do efeito persuasivo que emerge do conflito entre os dois argumentos devidamente contrapostos. Cabe esclarecer que a equipolência proclamada pelo cético não remete a afirmar uma identidade, mas sim que a força persuasiva de um argumento, ao ser contraposta à força persuasiva de outro, resulta em uma neutralidade que impossibilita definir uma suposta superioridade. Sob a chancela desta neutralidade, o cético mostra que a igualdade se mantém e que nesta contraposição os argumentos dispostos são incapazes de provar a inconsistência do adversário.

Anomalia: Devido a essa discordância contínua, pois não há um critério que nos leve a decidir, na contraposição de teses opostas, qual deteria a verdade, há tal discordância entre as coisas que o cético decide acautelar-se. Anomalia é o resultado da contraposição de teses posta pela equipolência. É a discordância que leva o indivíduo inquiridor a não aceitar a superioridade de (a) em relação a uma tese oposta (b). Diante desta situação de dissonância, o examinador supõe a não homogeneidade da tese (a) em relação a (b).

Epokhé: A suspensão do juízo que consiste na não asserção, como resultante da situação descrita acima. Ocorre que o sujeito inquiridor, não aceitando e nem refutando, ele não afirma e nem nega. A atitude cética, manifesta pela suspensão do juízo, evita o erro. Para o cético, o oposto de sua atitude é o dogmatismo que assente sobre coisas obscuras. A suspensão do juízo pirrônica refere-se à filosofia e, 
por isso, o cético reserva para si a conduta da vida como o espaço em que pode agir e assentir livremente, seguindo a aparência sensível e as normas da vida comum. A epokhé liberta o espírito, trazendo repouso mental, ou a imperturbabilidade.

Acatalepsia: Esse conceito é decorrente da epokhé e está intimamente ligado à ataraxia. A acatalepsia é a negação de que o conhecimento humano é capaz de "agarrar o objeto", se remetendo à atitude daquele que declara não compreender as coisas, nem negando ou afirmando nada. Para o cético pirrônico "tudo flui", ou seja, se algo aparece de um determinado modo, não há critério que garanta que esse aparecimento se reapresente do mesmo modo em outra situação. Como o objeto em si sempre nos escapa, pois não sabemos se em si mesmo ele é tal como nos aparece, cabe uma atitude de modéstia, não assentindo sobre coisas obscuras.

Ataraxia: Para os céticos a ataraxia é decorrente da epokhé, ambas caminham juntas e se complementam. Essa conexão entre epokhé e ataraxia é descoberta de modo acidental pela investigação pirrônica, mas a relação entre ambas não pode ser considerada um mero acidente. A suspensão do juízo é um estado de espírito que em si mesmo não traz a felicidade, mas somente acontece na decorrência da consequente quietude do espírito. A ataraxia é a ausência de perturbação e de inquietação, é a tranquilidade da alma ou imperturbabilidade do espírito. A ataraxia é o objetivo perseguido para as coisas opináveis no âmbito filosófico, já no âmbito da vida comum, em que temos que agir, cabe o uso da moderação. Quanto ao tema, eis o que nos apresenta Sexto:

[...] dando crédito às aparências segundo a observação vital, vivemos sem dogmatizar, já que não podemos permanecer completamente inativos. Parece, todavia, que esta observação vital é quádrupla e que uma parte descansa no guia da natureza, outra na compulsão das sensações, outra na tradição das leis e costumes e outra na instrução das artes. [...] Tudo o qual dizemos sem dogmatizar (H.P. I, Cap. XI, p. 91, 1996).

\section{CONSIDERAÇÕES FINAIS}

A natureza é um guia, e por meio dela somos capazes de sensações e conhecimento. Mas este aspecto do pensamento pirrônico precisa ser bem compreendido para não haver equívocos. Somos capazes de sensação, e daí ocorre a compulsão das sensações, tais como a própria fome que nos leva até a comida ou a sede que nos impõe a necessidade de bebermos água. Por conhecimento se entende duas coisas: 1) o bom uso das sensações com vistas a mantermos nossa saúde corporal; 2) manter a mente sã evitando maiores perturbações para o espírito. Neste sentido, tanto as aparências nos ensinam quanto as leis, a tradição, as artes, 
bem como as nossas amizades. Não há, para o cético, uma dicotomia entre sensação e razão, em que a última teria um total controle da primeira. O "antiracionalismo" cético mostra que a razão é enganadora, por isso as aparências devem governar nossas crenças. Conforme está posto nas Hipotiposis Pirrônicas:

[...] se opomos argumentos contra as aparências, não o fazemos desejando aboli-las, senão para mostrar a precipitação dos dogmáticos: pois se a razão é de tal modo enganadora que quase burla as aparências que estão ante nossos olhos, até que ponto nos será preciso considerá-la com suspicácia no caso dos objetos não evidentes, a fim de extraviar-nos seguindo-a? (H.P. I, Cap. X, p. 90, 1996)

Temos que entender que "o critério da orientação cética é a aparência, chamando assim virtualmente a percepção, pois o que jaz na convicção e na sensação involuntária é ininvestigável" (H.P. I, Cap. XI, p. 90, 1996). De acordo com a sensação passiva somos conduzidos involuntariamente a assentir sobre o que as aparências nos apresentam. Um exemplo clássico: "por exemplo, nos aparece que o mel seja doce (e o admitimos, pois o percebemos doce sensivelmente), mas investigamos se assim mesmo é doce segundo a razão, o que não é a aparência, senão o que se diz acerca da aparência" (H.P. I, Cap. XI, p. 90, 1996). Embora haja radicalidade no pensamento cético, a questão assim colocada mostra que negar que temos objetos de pensamento é um equívoco. Fatual é que temos objetos de pensamento, que são os juízos emitidos pela razão. Os céticos utilizam a suspensão do juízo para não assentir no que a razão procura justificar. Mas estas considerações levam o cético a calar-se totalmente sobre tudo? Em um primeiro momento, poderíamos afirmar que o percurso cético se encerraria em um absoluto silêncio. No entanto, isso não ocorre. De fato, se os céticos duvidassem por duvidar, o correto seria que se calassem definitivamente. No entanto, como vimos, os céticos defendem uma posição alicerçada sobre argumentos plausíveis, principalmente aqueles que identificam as dificuldades e as contradições dos dogmáticos. Neste sentido, os céticos alcançam um silêncio, mas não um absoluto silêncio que lhes apague a vontade de viver e a comunicação com outros seres humanos em suas vidas cotidianas. Este estado de silêncio alcançado pelos céticos, a afasia, não é um silêncio total. A afasia é um estado interior de paz desfrutado pelo indivíduo após a epokhé acerca das coisas não evidentes. Dizendo de outro modo, o silêncio alcançado pelo percurso cético é direcionado em abster a comunicação sobre coisas obscuras, silêncio este estritamente vinculado à suspensão do juízo.

O sentido da postura pirrônica está em sua proposta de atacar as pretensas verdades dos dogmáticos e acadêmicos, promovendo a vida comum. Ao separar a filosofia da esfera própria à vida comum, o cético percebe que essas duas instâncias contrapostas supõem diferentes modos de agir. Se os juízos sobre as coisas não evidentes, no plano filosófico, devem ser totalmente rechaçados, por outro lado, 
no plano da vida comum, nem todos os juízos sobre coisas não evidentes devem ser desprezados, considerando que os céticos, assim como todos os humanos, têm que agir. Quanto ao tema, como bem explica Smith:

Os filósofos, quando quiseram promover nossa felicidade, procuraram descrever uma maneira de viver que fosse superior à habitual. [...] Tudo isso com a finalidade de nos seduzirem e, cativando nossa imaginação, obterem nossa adesão para suas seitas. Tais filosofias, entretanto, se distanciam da vida cotidiana, já que esta é vista como uma maneira defeituosa ou equivocada de viver, da qual deveríamos, por meio da reflexão filosófica, nos afastar (SMITH, 2004, p. 52).

Para os céticos, as leis e os costumes levam a considerar que determinados atos são piedosos em detrimento de outros que não são. $O$ cético segue essas indicações conforme lhe convém, sem dogmatizar, sempre disposto a rever e refazer suas próprias crenças. Ademais, existe a necessidade de cultivar as artes, pois a instrução que foi legada por outros, bem como as que cultivamos e aprendemos por nós mesmos, nos ajudam a viver melhor. Por conseguinte, é diante da relação entre o inopinável e o opinável que se deve compreender o fim da filosofia cética. “Dizemos agora que o fim do cético é a imperturbabilidade no opinável e a moderação no necessário" (H.P. I, Cap. XII, p. 91, 1996). O inopinável é o plano filosófico que pretende determinar o que as coisas são em si mesmas. Como vimos, para os pirrônicos este projeto deve ser abandonado, visto que perturba o espírito sem alcançar o que propõe como sua finalidade. O opinável é a prática da vida, em que seguimos as aparências procurando viver da melhor forma possível. Aqui os céticos se sentem bem e vivem em conformidade com as tradições de sua cultura, em um retorno à simples vida comum.

\section{REFERÊNCIAS BIBLIOGRÁFICAS}

DIÔGENES, Laêrtios. Vidas e Doutrinas dos Filósofos Ilustres. Tradução do grego, introdução e notas: Mário da Gama Kury 2ª . Brasília: Ed. Universidade de Brasília, 1977.

FILHO, Roberto Bolzani. Acadêmicos versus Pirronianos: Ceticismo Antigo e Filosofia Moderna. In. Discurso. Revista do Departamento de Filosofia da USP. São Paulo: Discurso Editorial, n. 29, 1998. p. 57-111.

. A Epokhé Cética e seus Pressupostos. In. Discurso. Revista do Departamento de Filosofia da USP. São Paulo: Discurso Editorial, n. 27, 1996. p. 37-61. 
HADOT, Pierre. O que é a filosofia antiga?. Tradução: Dion Davi Macedo. São Paulo: Edições Loyola, 1999.

LANDESMAN, Charles. CETICISMO. Tradução: Cecília Camargo Bartalotti. São Paulo: Edições Loyola, 2006. (Coleção Leituras Filosóficas).

POPKIN, Richard H. História do Ceticismo de Erasmo a Spinosa. Tradução: Danilo Marcondes de Souza Filho. Rio de Janeiro: Francisco Alves, 2000.

PORCHAT, Oswaldo P. Rumo ao ceticismo. São Paulo: Editora UNESP, 2007. (Artigos publicados entre 1969 e 2005).

. Vida Comum e Ceticismo. São Paulo, Brasiliense, 1993.

PRADO, JR. Bento (org). A Filosofia e a visão comum do mundo. São Paulo: Brasiliense, 1981.

SEXTO EMPÍRICO. Hipotiposis Pirrónicas. Tradução e Edição: Rafael Sartorio Maulini. Madrid: Ediciones AKAL, 1996.

. Sextus Empiricus, in four volumes. BURY, R. G. (Ed.) The Loeb Classical Library. Cambridge, Massachusetts: Harvard University Press-Londom: William Heinemann ltd., 1976.

SMITH. P. J. Ceticismo Filosófico. São Paulo/Curitiba: EPU/Editora da UFPR, 2000.

CETICISMO. Rio de Janeiro: Jorge Zahar Ed., 2004. (Coleção passo-apasso; 35).

STROUD, Barry. El Escepticismo Filosófico y su Significación. Tradução: Letícia García Urriza. México: Fondo de Cultura Econômica, 1991. 